\title{
UPAYA MENINGKATKAN HASIL BELAJAR PKn MELALUI MODEL PEMBELAJARAN KOOPERATIF NUMBER HEAD TOGETHER PADA SISWA KELAS V SD NEGERI 24 TANJUNG BATU
}

\author{
SITI AISYAH \\ SDN 24 TANJUNG BATU
}

\begin{abstract}
ABSTRAK
Tujuan dari penelitian ini adalah untuk meningkatkan hasil belajar siswa kelas V pada SDN 24 Tanjung Batu dengan menggunakan model pembelajaran Kooperatif Number Head Together. Subjek penelitian ini adalah siswa kelas V SDN 24 Tanjung Batu Kec. Tanjung Batu Kabupaten Ogan Ilir.

Model NHT adalah bagian dari model pembelajaran kooperatif struktural, yang menekankan pada struktur-struktur khusus yang dirancang untuk mempengaruhi pola interaksi siswa. Struktur Kagan menghendaki agar para siswa bekerja saling bergantung pada kelompok-kelompok kecil secara kooperatif. Struktur tersebut dikembangkan sebagai bahan alternatif dari sruktur kelas tradisional seperti mangacungkan tangan terlebih dahulu untuk kemudian ditunjuk oleh guru untuk menjawab pertanyaan yang telah dilontarkan. Suasana seperti ini menimbulkan kegaduhan dalam kelas, karena para siswa saling berebut dalam mendapatkan kesempatan untuk menjawab pertanyaan peneliti.

Penelitiantindakankelas ini dilaksanakandalam 2 siklus, yang masingmasingsiklusterdiridaritahapperencanaan, tindakan, observasi, danrefleksi. Data yang diperolehdalampenelitianinimeliputi: kreativitassiswa yang diambildarihasil pengisian instrumen yang dilakukanoleh observer sebagaikolaboratifpenelitian padasaat proses belajarmengajarberlangsung. Hasil belajarsiswa yang diambildaripemberiansoaltespadasetiapakhirsiklus.

Indikatorkeberhasilandalampenelitianiniadalah Adanyapeningkatan hasil belajar

Pada siklus I indikator keberhasilan nilai siswa adalah ada 13 siswa yang telah mencapai KKM prosentase ketuntasan adalah 65,00 \% cukup. Sedangkan pada Siklus II indikator keberhasilan nilai siswa adalah 17 yang telah mencapai KKM 70 prosentase ketuntasan adalah 85,00 \% kategori Sangat Tinggi. Berarti ketuntasan belajar telah melampaui $75 \%$, indikator keberhasilan pembelajaran telah tercapai yaitu lebih dari $75 \%$ siswa Kelas V telah mencapai Kriteria ketuntasan Minimal 70.

Dengan demikian dapat disimpulkan bahwa pembelajaran dengan model pembelajaran number head together dapat meningkatkan hasil belajar PKn di kelas V SD Negeri 24 Tanjung Batu.
\end{abstract}

\section{Kata Kunci : Number Head Together,Hasil Pembelajaran.}




\section{PENDAHULUAN}

Undang-Undang Republik Indonesia Nomor 20 Tahun 2003 Tentang Sistem PendidikanNasional Pasal 3 menegaskan bahwa fungsi dan tujuan pendidikannasional adalah untuk mengembangkan kemampuan dan membentuk watak serta peadaban bangsa yang bermartabat dalam rangka mencersdaskan kehidupan bangsa, bertujuan untuk berkembangnya potensi peserta didik agar menjadi manusia yang beriman dan bertakwa kepada Tuhan Yang Maha Esa, berakhlak mulia, sehat, berilmu, cakap, kreatif, mandiri dan menjadi warga Negara yang demokratis serta bertanggung jawab.

Pembelajaran PKn merupakan mata pelajaran yang memfokuskan pembentukn diri yang beragam dari segi agama, sosial kultur, bahasa, usia, suku, bangsa dan untuk menjadi warga negara indonesia yang cerdas, terampil dan berkarakter yang diamatkan oleh pancasila dan UUD 1945. Fungsinya adalah sebagai wahana untuk membentuk warga negara yang cerdas, terampil, berkarakter, yang setia kepada bangsa dan negara Indonesia dengan merefleksikan dirinya dalam kebiasaan berpikir dan bertindak sesuai dengan amanat Pancasila dan UUD 1945

Pada pelaksanaannya di lapangan, proses pembelajaran yang ada masih banyak menerapkan metode konvensional dengan menggunakan ceramah dalam menyampaikan materi. Sehingga dengan metode ini siswa hanya akan mendengarkan materi yang disampaikan oleh guru. Dapat dikatakan siswa menjadi individu yang pasif. Sementara itu, kurikulum yang ada saat ini menuntut siswa yang berperan aktif dalam membangun konsep dalam diri. Jadi kegiatan belajar berpusat pada siswa, guru sebagai motivator dan fasilitator di dalamnya agar suasana kelas menjadi hidup.

Oleh karena itu, guru perlu mengetahui serta memahami suatu model pembelajaran lain yang sesuai digunakan pada sekarang ini. Salah satu model tersebut adalah model pembelajaran cooperative Number Head Together yang akan dibahas lebih lanjut dalam penelitian ini.

Berdasarkan masalah itu peneliti menyadari sepenuhnya masalah-masalah yang selalu muncul dalam kegiatan pembelajaran. Kadang-kadang guru menjadi bingung dalam menentukan model pembelajaran atau model mengajar apa yang akan digunakan dalam proses pembelajaran. Harapan untuk memiliki siswa yang cerdas, dan terampil secara aktif dan kreatif, sehingga hasil yang memuaskan pada setiap tes kadang tidak tercapai. Kenyataan yang dijumpai malah sebaliknya. Siswa kurang aktif dalam pembelajaran, kurang bersemangat dalam menerima pelajaran, serta kurang percaya diri, dalam menjawab pertanyaan dari guru, sehingga mengakibatkan hasil prestasi yang rendah dan mengecewakan. Itu menandakan bahwa pembelajaran dapat dikatakan belum berhasil. Hal ini terbukti dari hasil evaluasi nilai siswa pada mata pelajaran PKn sangat rendah karena tidak mencapai KKM yang telah ditetapkan. 
Setelah Dilakukan analisa, hasil ulangan kelas V yang berjumlah 20 orang didapat data hasil belajar sebagai berikut : 2 siswa terlampuai $(10,00 \%), 4$ siswa tercapai $(20,00 \%)$, dan 14 siswa tidak tercapai $(70,00 \%)$, siswa telah mencapai KKM70 ada 6 siswa secara klasikal prosentase ketuntasan adalah 30,00\%. Untuk mengoptimalkan pembelajaran PKn di SD salah satu alternatif yang dapat dilakukan ialah melalui model pembelajaran kooperatif Number Head Together, model pembelajaran kooperatif Number Head Together dapat memberikan kesempatan pada anak untuk mengembangkan kemampuan emosional, fisik, sosial, dan nalar siswa, melalui interaksinya dengan pembelajaran. Dengan adanya model pembelajaran kooperatif Number Head Together diharapkan siswa mampu mengembangkan keterampilan di dalam kelompok-kelompok, mampu bekerja sama dengan baik guna mencapai suatu tujuan pembelajaran. Hingga proses pembelajaran berjalan dengan baik.

Dari latar belakang di atas maka tujuan penelitian ini adalah "Meningkatkan hasil belajar PKn dengan menggunakan Model Pembelajaran Kooperatif Number Head Together".

\section{METODE}

\section{Hasil Belajar}

Menurut Degeng (Wena , 2009: 6) "Hasil pembelajaran adalah semua efek yang dapat dijadikan sebagai indikator tentang nilai dari penggunaan strategi pembelajaran dibawah kondisi yang berbeda". Sedangkan Mulyasa (2009:212) menyebutkan bahwa "hasil belajar merupakan prestasi belajar peserta didik secara keseluruhan yang menjadi negara kompetensi dasar dan derajat perubahan perilaku yang bersangkutan.

\section{Model Pembelajaran NHT}

Menurut Sanjaya (2010:242) Pembelajaran kooperatif merupakan model pembelajaran dengan menggunakan sistem pengelompokkan/tim kecil, yaitu antara empat sampai enam orang yang mempunyai latar belakang kemampuan akademik, jenis kelamin, ras, atau suku yang berbeda (heterogen). Setiap kelompok akan memperoleh penghargaan (reward), jika kelompok mampu menunjukkan prestasi yang dipersyaratkan.

\section{Lokasi dan Subjek Penelitian}

Lokasi Penelitian adalah SD Negeri 24 Tanjung Batu beralamat di Jalan Puskesmas Dusun V Sritanjung Kabupaten Ogan Ilir Provinsi Sumatera Selatan.

\section{Teknik dan Alat Pengumpulan Data}

Pengumpulan data dilakukan dengan menggunakan observasi dan tes 


\section{Analisis Data}

Teknik analisa data menggunakan rumus teknik proporsi dengan rumus :

$$
\mathrm{D}=[\mathrm{A} / \mathrm{N}] \times 100 \%
$$

Dimana :

$\mathrm{D}$ :prosentase siswa yang tuntas

A :Jumlah siswa yang tuntas

$\mathrm{N}$ :Jumlah seluruh siswa (Sudjana, 2010)

Hasil analisis data disajikan dalam bentuk data, table dan grafik untuk memudahkan dalam membaca data dan memprediksi kesimpulan apa yang diambil dari penelitian yang dilakukan.

\section{HASIL PENELITIAN DAN PEMBAHASAN}

\section{Hasil Penelitian Siklus 1}

Hasil penelitian pada siklus I berupa data hasil olah nilai tes terhadap siswa diakhir siklus I untuk memperoleh nilai hasil belajar siswa selama dua kali pertemuan.

\section{Data Hasil Belajar PKn Siswa Siklus I}

Data hasil belajar PKn siswa pada akhir siklus I dapat dilihat pada tabel 5 berikut :

Tabel 5 : Hasil Belajar Siswa pada Akhir Siklus I

\begin{tabular}{|c|c|c|c|c|}
\hline No & Nilai & $\begin{array}{c}\text { Jumlah } \\
\text { Siswa }\end{array}$ & Tuntas & $\begin{array}{c}\text { Tak } \\
\text { Tuntas }\end{array}$ \\
\hline 1 & $<49$ & 2 & - & 2 \\
\hline 2 & $50-59$ & 3 & - & 3 \\
\hline 3 & $60-69$ & 2 & - & 2 \\
\hline 4 & $70-79$ & 8 & 8 & - \\
\hline 5 & $80-89$ & 2 & 2 & - \\
\hline 6 & $90-100$ & 3 & 3 & - \\
\hline \multicolumn{2}{|c|}{ Jumlah } & 20 & 13 & 7 \\
\hline
\end{tabular}

Berdasarkan tabel 5 di atas menunjukan hasil belajar siswa setelah siklus I telah memenuhi standar ketuntasan minimum 70 sebesar $65,00 \%$. Nilai siswa tidak menyebar merata, sebagian besar pada kisaran 70-79 dengan nilai rata-rata 40,00\% maka dapat dikatakan pada siklus I hasil belajar siswa belum optimal dan oleh karena itu perlu ditingkatkan pada siklus selanjutnya. Secara rinci dapat dilihat dalam gambar 2 di bawah ini : 


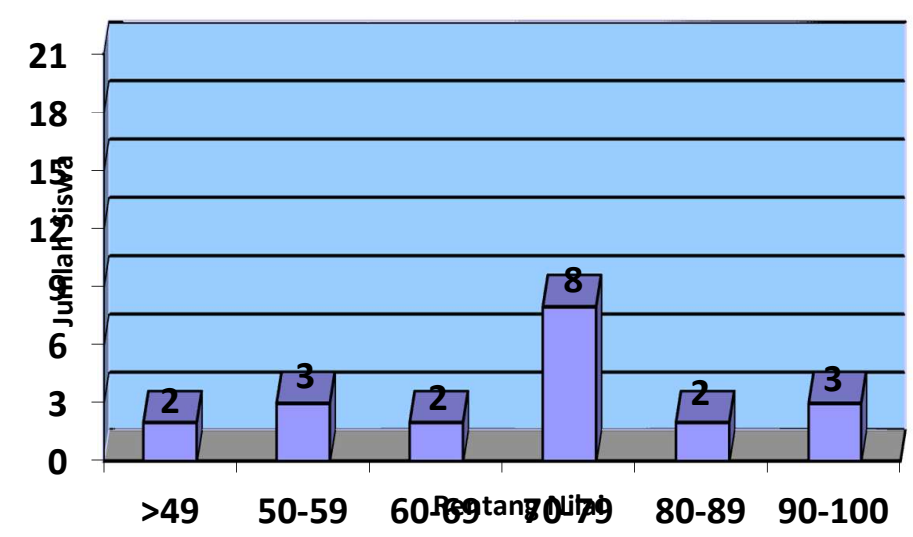

Tabel : 6 Indikator keberhasilan Nilai akhir siswa siklus I

\begin{tabular}{|c|c|c|c|}
\hline No & $\begin{array}{c}\text { Prosentase } \\
\text { Ketuntasan }\end{array}$ & Katagori & Nilai Akhir \\
\hline 1 & $\geq 80 \%$ & sangat tinggi & 5 \\
\hline 2 & $70 \%-79 \%$ & Tinggi & 8 \\
\hline 3 & $60 \%-69 \%$ & Cukup & 2 \\
\hline 4 & $50 \%-59 \%$ & Kurang & 3 \\
\hline 5 & $\leq 49$ & sangat kurang & 2 \\
\hline
\end{tabular}

Indikator keberhasilan nilai siswa adalah 2 siswa dengan nilai sangat kurang, 3 siswa dengan kurang, 2 siswa memperoleh nilai cukup, 8 siswa memperoleh nilai tinggi dan 5 siswa memperoleh nilai sangat tinggi rata-rata siswa memperoleh nilai tinggi, jadi jumlah siswa yang telah melampaui KKM 70 ada 13 siswa prosentase ketuntasan adalah $65,00 \%$ : cukup

\section{Refleksi Siklus I}

Berdasarkan hasil pengamatan dari pelaksanaan pembelajaran ditemukan hal-hal seperti dibawah ini :

- Proses pembelajaran dengan model pembelajaran kooperatif Number Head Together merupakan pengalaman baru bagi siswa, sehingga kesiapan siswa masih kurang.

- Minat dan motivasi kurang.

- Belum terbiasanya siswa mengoptimalkan kemampuan hingga kelihatan masih bingung dalam penggunaan model pembelajaran kooperatif Number Head Together.

\section{Hasil Penelitian Siklus II}

Data yang diperoleh dalam siklus II berupa data hasil olah nilai tes terhadap siswa diakhir siklus II untuk memperoleh nilai hasil belajarnya. 


\section{Data Hasil Belajar PKn Siswa Siklus II}

Data hasil belajar PKn siswa pada akhir siklus II dapat dilihat pada tabel 8berikut :

Tabel 8: Data Hasil Belajar Siswa pada Akhir Siklus II

\begin{tabular}{|c|c|c|c|c|}
\hline No & Nilai & $\begin{array}{c}\text { Jumlah } \\
\text { Siswa }\end{array}$ & Tuntas & $\begin{array}{c}\text { Tak } \\
\text { Tuntas }\end{array}$ \\
\hline 1 & $<49$ & - & - & - \\
\hline 2 & $50-59$ & - & - & - \\
\hline 3 & $60-69$ & 3 & - & 3 \\
\hline 4 & $70-79$ & 6 & 6 & - \\
\hline 5 & $80-89$ & 7 & 7 & - \\
\hline 6 & $90-100$ & 4 & 4 & - \\
\hline \multicolumn{2}{|c|}{ Jumlah } & 20 & 17 & 3 \\
\hline
\end{tabular}

Berdasarkan tabel 8 di atas menunjukan hasil belajar siwa setelah siklus II telah memenuhi standar ketuntasan belajar minimum 70 sebesar 85,00\%. Nilai siswa sebagian besar pada kisaran 80-89 dengan nilai 35,00 \% yang dikategorikan tinggi, jadi jumlah siswa yang mencapai nilai KKM 70 adalah 17 siswa prosentase ketuntasan adalah 85,00 maka dapat dikatakan pada siklus II hasil belajar siswa sudah optimal. Secara rinci dapat dilihat dalam gambar 4 berikut :

Gambar 2 : Grafik Hasil Belajar PKn Siswa pada Siklus II

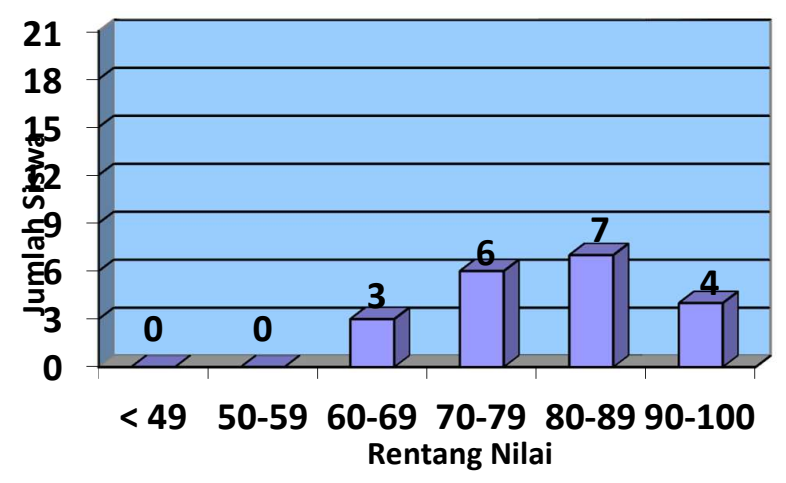

Tabel 9 : Indikator keberhasilan Nilai akhir siswa siklus II

\begin{tabular}{|c|c|c|c|}
\hline No & $\begin{array}{c}\text { Prosentase } \\
\text { Ketuntasan }\end{array}$ & Kategori & Jumlah Siswa \\
\hline 1 & $\geq 80 \%$ & sangat tinggi & 11 \\
\hline 2 & $70 \%-79 \%$ & Tinggi & 6 \\
\hline 3 & $60 \%-69 \%$ & Cukup & 3 \\
\hline 4 & $50 \%-59 \%$ & kurang & 0 \\
\hline 5 & $\leq 49$ & sangat kurang & 0 \\
\hline
\end{tabular}


Indikator keberhasilan nilai siswa adalah 3 siswa dengan nilai cukup, 6 siswa dengan nilai tinggi dan 11 siswa memperoleh nilai sangat tinggi rata-rata siswa memperoleh nilai sangat tinggi, jumlah siswa tuntas adalah 17 siswa prosentase ketuntasan adalah 85,00 kategori Sangat Tinggi.

\section{Refleksi Siklus II}

Secara umum pada siklus kedua ini terlihat motivasi dan semangat siswa dalam pembelajaran lebih meningkat dibanding siklus pertama. Pada siklus kedua ini tampak siswa mengalami peningkatan pemahaman materi yang dipelajari. Kemampuan siswa mengembangkan materi lebih luas yang berdampak terhadap peningkatan hasil belajar. Hal ini menunjukan bahwa siswa sudah memahami dan menikmati model pembelajaran kooperatif Number Head Together.

Berdasarkan pada pengamatan dalam proses pembelajaran ditemukan halhal berikut :

- Siswa mulai berani mengemukakan pendapat pada kelompoknya karena merasa leluasa dalam berinteraksi.

- Siswa menyampaikan gagasan yang bervariasi sehingga dalam penyelesaian masalah memerlukan waktu yang agak lama.

- Siswa sudah terbiasa dengan pembelajaran model pembelajaran kooperatif Number Head Together, sehingga pembelajaran berlangsung sesuai dengan rencana pembelajaran.

- Pemberian penghargaan kepada siswa yang aktif menumbuhkan semangat bagi yang lain dan mendorong terhadap penguasaan materi.

\section{Hasil Penelitian Peningkatan Hasil Belajar Siswa Akhir Siklus I danSiklus II}

Proses pembelajaran yang telah dilakukan, telah mengarah pada peningkatan keaktifan belajar siswa dan akhirnya berpengaruh pada hasil belajar siswa. Berdasarkan data nilai yang diperoleh dari tes yang diberikan pada siswa pada akhir setiap siklus pada penelitian tindakan kelas ini, model pembelajaran kooperatif Number Head Together menunjukan adanya peningkatan pada hasil belajar siswa. Peningkatan hasil belajar siswa pada mata pelajaran PKn secara jelas dapat dilihat pada tabel 10 berikut ini :

Tabel 10 : Data Peningkatan Hasil belajar Siswa akhir siklus I dan siklus II

\begin{tabular}{|c|c|c|c|c|}
\hline No & $\begin{array}{c}\text { Prosentase } \\
\text { Ketuntasan }\end{array}$ & Kategori & $\begin{array}{c}\text { Nilai } \\
\text { Akhir } \\
\text { Siklus 1 }\end{array}$ & $\begin{array}{c}\text { Nilai } \\
\text { Akhir } \\
\text { Siklus II }\end{array}$ \\
\hline 1 & $\geq 80 \%$ & sangat tinggi & 5 & 11 \\
\hline 2 & $70 \%-79 \%$ & tinggi & 8 & 6 \\
\hline 3 & $60 \%-69 \%$ & cukup & 2 & 3 \\
\hline 4 & $50 \%-59 \%$ & kurang & 3 & 0 \\
\hline 5 & $\leq 49$ & sangat kurang & 2 & 0 \\
\hline
\end{tabular}


Pada siklus I Indikator keberhasilan nilai siswa adalah jumlah siswa yang tuntas mencapai KKM 70 adalah 13 siswa prosentase ketuntasan klasikal adalah $65,00 \%$ kategori: cukup

Sedangkan pada Siklus II Indikator keberhasilan siswa yang tuntas mencapai KKM 70 adalah 17 siswa prosentase ketuntasan klasikal adalah 85,00\% kategori: Sangat Tinggi.

Indikator keberhasilan adalah $75 \%$ siswa mencapai KKM 70 sedangkan dalam penelitian ini $85,00 \%$ siswa telah mencapai KKM jadi penelitian ini telah berhasil meningkatkan hasil belajar PKn Siswa kelas V melalui model pembelajaran kooperatif Number Head Together.

Tabel 11: Peningkatan Hasil belajar

\begin{tabular}{|c|c|c|}
\hline Penelitian & Tuntas \% & Tidak Tuntas \\
\hline \hline Pra Penelitian & 30,00 & 70,00 \\
\hline Akhir Siklus I & 65,00 & 35,00 \\
\hline Akhir Siklus II & 85,00 & 15,00 \\
\hline
\end{tabular}

Berdasarkan tabel 11 di atas, dapat dilihat hasil peningkatan ketuntasan secara klasikal pra penelitian 30,00\% ke siklus I terjadi peningkatan hasil belajar menjadi $65,00 \%$, ke siklus II menjadi $85,00 \%$ jadi pembelajaran dengan menggunakan model pembelajaran kooperatif Number Head Together dinyatakan Berhasil karena sudah mencapai tingkat ketuntasan diatas $75 \%$ yaitu 85,00\%. Peningkatan hasil belajar yang terjadi dikarenakan siswa lebih cepat mengingat materi pelajaran dengan penerapan model pembelajaran kooperatif Number Head Together dan proses pembelajaran disesuaikan dengan rencana pelaksanaan pembelajaran yang telah disusun. Siswa terlihat sangat terbantu dengan adanya model pembelajaran kooperatif Number Head Together.

Dalam proses pembelajaran siswa dapat mendengar, melihat dan mencari sendiri jawaban dari permasalahan yang mereka hadapi yang akhirnya mereka dapat dengan mudah menyelesaikan permasalahan dan soal-soal yang diberikan dengan penerapan pembelajaranini. Dengan demikian tampak bahwa penerapan model pembelajaran kooperatif Number Head Together dapat meningkatkan hasil belajar siswa pada mata pelajaran PKn Secara lebih rinci dapat dilihat pada gambar 3.di bawah ini : 


\title{
Gambar3 : Grafik Peningkatan Hasil Belajar
}

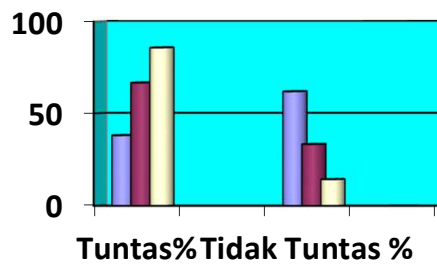

\author{
$\square$ Pra Penelitian \\ $\square$ Akhir Siklus 1 \\ $\square$ Akhir Siklus II
}

Pada gambar 3 menunjukan bahwa nilai rata-rata yang dicapai sebagai hasil belajar siswa pada siklus II lebih tinggi dibanding siklus I demikian juga dengan ketuntasan klasikalnya.

Hasil penelitian ini senada dengan apa yang dikemukakan oleh Spencer Kagan, dkk (Ibrahim, 2000 : 25). Model NHT adalah bagian dari model pembelajaran kooperatif struktural, yang menekankan pada struktur-struktur khusus yang dirancang untuk pola interaksi siswa. Number Head Together adalah suatu Model pembelajaran yang lebih mengedepankan kepada aktivitas siswa dalam mencari, mengolah, dan melaporkan informasi dari berbagai sumber yang akhirnya dipresentasikan di depan kelas (Rahayu, 2006).

NHT pertama kali dikenalkan oleh Spencer Kagan dkk (1993). Model NHT adalah bagian dari model pembelajaran kooperatif struktural, yang menekankan pada struktur-struktur khusus yang dirancang untuk mempengaruhi pola interaksi siswa. Struktur Kagan menghendaki agar para siswa bekerja saling bergantung pada kelompok-kelompok kecil secara kooperatif. Struktur tersebut dikembangkan sebagai bahan alternatif dari sruktur kelas tradisional seperti mangacungkan tangan terlebih dahulu untuk kemudian ditunjuk oleh guru untuk menjawab pertanyaan yang telah dilontarkan. Suasana seperti ini menimbulkan kegaduhan dalam kelas, karena para siswa saling berebut dalam mendapatkan kesempatan untuk menjawab pertanyaan peneliti (Tryana, 2008).

\section{SIMPULAN}

\section{Simpulan}

Dari data yang telah dibahas pada siklus 1 dengan hasil belajar tuntas 65,00 $\%$ tidak tuntas $35,00 \%$ prosentase keberhasilan belajar siklus 1 adalah $65,00 \%$ peningkatan hasil belajar dari pra siklus 35,00\%, siklus 2 diperoleh hasil belajar dengan rincian ketuntasan hasil belajar 85,00 \% yang tidak tuntas $15,00 \%$ peningkatan dari siklus $120,00 \%$ jadi dapat disimpulkan bahwa penelitian memang dapat meningkatkan hasil belajar siswa pada mata pelajaran PKn melalui model 
pembelajaran kooperatif Number Head Together pada siswa SD Negeri 24 Tanjung Batu.

\section{Saran}

1. Berdasarkan hasil penelitian ini menunjukkan bahwa model pembelajaran kooperatif Number Head Together dapat meningkatkan hasil belajar PKn Siswa Kelas V SDN 24 Tanjung Batu. Berdasarkan hal ini disarankan kepada guru untuk menggunakan pembelajaran model pembelajaran kooperatif Number Head Together sebagai variasi pembelajaran PKn atau mata pelajaran lain. Penerapan pembelajaran model pembelajaran kooperatif Number Head Together yang diterapkan adalah untuk memberikan kesempatan kepada siswa agar dapat terlibat secara aktif dalam proses berpikir dan dalam kegiatankegiatan belajar artinya pembelajaran benar benar berfokus pada siswa ( siswa centris).

2. Penelitian ini adalah Penelitian Tindakan Kelas yang terbatas pada variabel bebas pembelajaran model pembelajaran kooperatif Number Head Together sedangkan variabel terikat adalah hasil belajar. Lokasi penelian di SD Negeri 24 Tanjung BatuKabupaten Ogan Ilir Propinsi Sumatera Selatan. Agar dapat memperoleh pengetahuan yang luas diharapkan ada peneliti lain mau mengadakan penelitian serupa hingga pembelajar dengan menggunakan model pembelajaran kooperatif Number Head Together dapat benar benar teruji dan mampu meningkatkan hasil belajar pada semua jenis kelas dengan sekolah yang berbeda.

\section{REFERENSI}

Sudjana, Nana. 2001. Penilaian Hasil Belajar Mengajar. Bandung : Remaja Rosda Karya

Sanjaya. 2010. Proses belajar Mengajar. Jakarta : Bumi Aksara

Wena, Made. 2009. Strategi Pembelajaran Inovatif Kontemporer. Jakarta : Bumi Aksara 